\title{
Identifikasi Makroalga di Perairan Moudolung Kabupaten Sumba Timur
}

\author{
Yatris Rambu Tega ${ }^{1)}$, Firat Meiyasa*2), Krisman Umbu Henggu ${ }^{3)}$, \\ Nurbety Tarigan ${ }^{4)}$, Suryaningsih Ndahawali ${ }^{5}$ \\ 1,2,3,4,5 Program Studi Teknologi Hasil Perikanan, Fakultas sains dan Teknologi \\ Universitas Kristen Wira Wacana Sumba. Jl. R. Suprapto, No. 35, Waingapu-Sumba Timur \\ Email: yatrisrambutega@unkriswina.ac.id \\ *Email: firatmeiyasa@unkriswina.ac.id* \\ Email: krisman@unkriswina.ac.id \\ Email: nurtarigan@unkriswina.ac.id \\ Email: ningsih@unkriswina.ac.id
}
APA Citation: Tega, Y,R., Meiyasa, F., Henggu, K,U., Tarigan, N., Ndahawali, S., (2020). Identifikasi Makroalga di Perairan Moudolung Kabupaten Sumba Timur. Quagga: Jurnal Pendidikan dan Biologi, 12(2), 202-210, doi: 10.25134/quagga.v12i2.2751.

Received: 23-04-2020

Accepted: 25-06-2020

Published: 01-07-2020

\begin{abstract}
Abstrak: Makroalga merupakan sumberdaya hayati laut yang banyak ditemui di perairan Indonesia, salah satunya di Perairan Sumba Timur. Namun, sampai saat ini penyebaran makroalga di perairan Sumba Timur belum diidentifikasi spesiesnya. Langkah awal yang kami lakukan adalah memulai identifikasi makroalga di perairan Moudolung, alasanyanya penyebaran makroalga cukup melimpah. Tujuan dari penelitian ini adalah untuk mengidentifikasi setiap spesies makroalga yang tersebar di perairan Moudolung. Jenis penelitian yang digunakan adalah penelitian survei. Pengambilan sampel dilakukan pada tiga titik yaitu stasiun I (berpasir), stasiun II (lamun) dan stasiun III (berbatu), selanjutnya dilakukan identifikasi makroalga. Sampel makroalgae yang diperoleh diidentifikasi dengan menggunakan buku identifikasi makroalgae. Selain itu, juga dilakukan pengujian kualitas air (suhu, DO dan pH). Hasil penelitian menunjukkan bahwa kualitas air di perairan Moudolung cukup baik dengan rata-rata suhu adalah $29^{\circ} \mathrm{C}$, DO sebesar 7.7-8.1mg/L dan pH sebesar 8.30-8.40. Sementara untuk hasil identifikasi makroalga terdapat 3 kelas utama makroalga yaitu alga cokelat 7 spesies (Hormophysa triquetra, Sargasssum muticum, Turbinaria ornata (Turner) J. Agardh, Sargasum plagyophyllum, Sargassum polycystum, Dictyota pinnatifida dan Padina australis), alga merah 5 spesies (Gracilaria corticata, Eucheuma spinosum, Gracilaria salicornia C. Agaradh, Achanthopora spicifera dan Achanthopora muscoides), dan alga hijau 3 spesies (Ulva flexuosa, Ulva reticulate dan Ulva compressa L.).
\end{abstract}

Kata kunci: Makroalga; Keanekaragaman; Eksplorasi; Sumba Timur; Moudolung.

Abstract: Macroalgae is a marine biological resource that is commonly found in Indonesian waters, one of which is in East Sumba. However, to date the distribution of macroalgae in the waters of East Sumba has not been identified. The first step we took was to start identifying macroalgae in Moudolung waters, the reason being that the distribution of macroalgae was quite abundant. The purpose of this study was to identify each macroalgae species spread in Moudolung waters. This type of research is a survey research. Sampling was carried out at three points, namely station I (sandy), station II (seagrass) and station III (rocky), then macroalgae identification was carried out. Macroalgae samples obtained were identified using a macroalgae identification book. In addition, water quality testing (temperature, $\mathrm{DO}$, and $\mathrm{pH}$ ) was also carried out. The results showed that the water quality in Moudolung waters was quite good with an average temperature was $29^{\circ} \mathrm{C}, \mathrm{DO}$ was 7.7-8.1mg / L and pH was 8.30-8.40. Meanwhile, the results of macroalgae identification there are 3 major classes, namely 7 species of brown algae (Hormophysa triquetra, Sargasssum muticum, Turbinaria ornata (Turner) J. Agardh, Sargasum plagyophyllum, Sargassum polycystum, Dictyota pinnatifida and Padina australis) Turner J. J. Agardh, Sargasum plagyophyllum, Sargassum polycystum, Dictyota pinnatifida and Padina australis) Turn to J. Agardh, Sargasum plagyophyllum, Sargassum polycystum, Dictyota pinnatifida and Padina australis), Eucheuma spinosum, Gracilaria salicornia C. Agaradh, Achanthopora spicifera and Achanthopora muscoides), and 3 species of green algae (Ulva flexuosa, Ulva reticulate and Ulva compressa L.).

Keywords: Macroalgae; Diversity; Exploration; East Sumba; Moudolung. 


\section{PENDAHULUAN}

Indonesia merupakan salah satu negara yang memiliki keanekaragaman hayati (biodiversity) yang sangat tinggi, termasuk keanekaragaman hayati lautnya. Salah satu organisme laut yang banyak dijumpai hampir di seluruh pantai di Indonesia adalah makroalga (Marianingsih et al, 2013). Perairan Indonesia memiliki sumberdaya plasma nutfah makroalga sebesar $6,42 \%$ dari total biodiversitas makroalga dunia (Santosa et al, 2004).

Makroalga adalah salah satu kelompok tumbuhan tingkat rendah yang memiliki klorofil yang terdiri dari satu atau banyak sel dan berbentuk koloni (Pakidi dan Suwoyo 2017). Makroalga di alam hidup menempel pada substrat yang stabil untuk menjaga posisinya agar tidak hanyut terbawa oleh arus, gelombang, dan pasang surut (Radiarta dan Erlania 2015). Makroalga sangat mudah untuk beradaptasi di semua jenis substrat, termasuk menempel di bagian karang hidup yang mengalami pelapukan (Dhargalkar dan Devanand 2004).

Menurut hasil kajian oleh LIPI pada Tahun 2017 ternyata Indonesia memiliki total 903 spesies dan 268 marga yang terdiri dari rumput laut hijau/Chlorophyta (201 spesies), coklat/Ochrophyta (138 spesies) dan merah/Rhodophyta (564 spesies) (Handayani 2017).

Penyebaran makroalga di beberapa wilayah perairan Indonesia telah dilaporkan seperti perairan Jepara, Yogyakarta, Pangandaran, Garut, Pacitan, Kepulauan Spermonde, Sulawesi Selatan, Sulawesi Tenggara, Sulawesi Tengah, Pulau Bali, Pulau Sumbawa, Perairan Maluku, perairan teluk Aceh Selatan, Kabupaten Takalar, Kabupaten Pacitan, Kabupaten Pulau Morotai, Kepulauan Riau (Nurafni et al. 2020; Fitria et al. 2019; Dwimayasanti \& Kurnianto 2018; Kurniawan 2018; Setyawan et al. 2015).

Informasi terkait penyebaran makroalga di Indonesia samapai saat ini telah banyak dilaporkan oleh para peneliti. Namun, informasi penyebaran makroalga di perairan Sumba hampir tidak ada. Sementara diketahui bahwa makroalga cukup melimpah di perairan Sumba. Berdasarkan hal tersebut maka tujuan dari penelitian ini adalah untuk mengidentifikasi jenis-jenis makroalga yang terdapat di perairan Moudolung. Diharapkan penelitian ini dapat dijadikan sebagai informasi dasar yang nantinya akan dikembangkan ke arah pangan fungsional nantinya.

\section{METODOLOGI PENELITIAN Alat dan Bahan}

Adapun alat digunakan dalam penelitian ini adalah $\mathrm{pH}$ meter, DO meter, meter rol, tali rafia, tali nilon, coolbox, cutter, gelas kimia, plastik sampel, dan alat tulis menulis. Sementara bahan yang digunakan dalam penelitian ini adalah alkohol $70 \%$, aquades, dan tissue.

\section{Prosedur Penelitian}

Jenis penelitian yang digunakan adalah penelitian survei. Pengambilan sampel dilakukan pada tiga titik yaitu stasiun I (berpasir), stasiun II (lamun) dan stasiun III (berbatu) dengan cara survei jelajah dengan luar area pengambilan sampel kurang lebih $50 \times 50$ m. Sampel tersebut kemudian dicuci bersih, ditaruh dalam plastik bening di simpan dalam coolbox dan dibawa ke laboratorium untuk dilakukan identifikasi. Sampel makroalga yang diperoleh diidentifikasi dengan menggunakan buku identifikasi makroalga menurut Cordero (1980); Dawson (1966); dan Taylor (1960). Sementara untuk pengujian kualitas air (suhu, DO dan $\mathrm{pH}$ ) menggunakan DO meter dan $\mathrm{pH}$ meter.

\section{HASIL DAN PEMBAHASAN \\ Kualitas Perairan Moudolung}

Kualitas air begitu penting bagi organisme di suatu perairan untuk kelangsungan hidupnya, juga harus memenuhi standar baik parameter fisika maupun parameter kimia. Berikut beberapa parameter fisikokimia yang telah diukur di pesisir pantai Moudolung Sumba Timur, meliputi; DO, pH, dan suhu. Hasil penelitian menunjukkan bahwa $\mathrm{pH}$, Suhu, dan DO (Tabel 1) telah sesuai dengan SNI dimana kisaran suhu 25- $30{ }^{\circ} \mathrm{C}$. $\mathrm{pH}$ 6.8-8.2, DO >3.0 (SNI 7904:2013). Hal ini juga sesuai dengan hasil penelitian yang dilaporkan oleh Aslan (1991) dan Lapu (2013) dengan kisaran $\mathrm{pH}$ sebesar 7.2-8.2, suhu sekitar $24-36^{\circ}$ Cdan DO sebesar 7,7 mg/L.

Tabel 1. Parameter Kualitas Perairan

\begin{tabular}{clccc}
\hline No & Parameter & S1 & S2 & S3 \\
\hline 1 & DO $(\mathrm{mg} / \mathrm{L})$ & 8.0 & 8.1 & 7.6 \\
2 & $\mathrm{pH}$ & 8.33 & 8.40 & 8.30 \\
3 & Suhu $\left({ }^{\circ} \mathrm{C}\right)$ & 29.8 & 29.8 & 29.7 \\
\hline
\end{tabular}

Ket: S1=Stasiun 1, S2=Stasiun 2, S3=Stasiun 3 


\section{Klasifikasi Makroalga}

Rumput laut dapat diklasifikasikan menjadi tiga kelompok besar berdasarkan pigmentasi. Ahli botani menyebut masing-masing kelompok besar ini sebagai Phaeophyceae, Rhodophyceaea dan Chlorophyceaea (Messyasz et al. 2015).

Rumput laut cokelat biasanya besar dan panjangnya $30 \mathrm{~cm}$ sampai $20 \mathrm{~m}$ dengan ketebalan 2-4 m. Rumput laut merah biasanya lebih kecil umumnya berkisar dari beberapa sentimeter hingga sekitar satu meter panjangnya. Namun, rumput laut merah tidak selalu merah, kadang-kadang berwarna ungu, bahkan merah kecoklatan, tetapi masih diklasifikasikan oleh ahli botani sebagai Rhodophyceae karena karakteristik lain. Rumput laut hijau juga kecil dengan ukuran yang mirip dengan rumput laut merah. Berikut adalah hasil penelitian yang telah dilakukan di perairan Moudolung Kabupaten Sumba Timur NTT, terdapat tiga klasifikasi rumput laut, dapat dilihat pada Tabel 2, Tabel 3, dan Tabel 4.

Tabel 2. Klasifikasi Alga Coklat (Phaephyta)

\begin{tabular}{|c|c|c|c|c|c|}
\hline Divisi & Kelas & Ordo & Famili & Genus & Spesies \\
\hline Phaeophyta & Phaeophyceae & Fucales & Cystoseiraceae & Hormophysa & Hormophysa triquetra \\
\hline Phaeophyta & Phaeophyceae & Fucales & Sargassaceae & Sargassum & Sargasssum muticum \\
\hline Phaeophyta & Phaeophyceae & Fucales & Phaeophyceae & Turbinaria & $\begin{array}{l}\text { Turbinaria ornata } \\
\text { (Turner) J. Agardh }\end{array}$ \\
\hline Phaeophyta & Phaeophyceae & Fucales & Sargassceae & Sargassum & $\begin{array}{l}\text { Sargasum } \\
\text { plagyophyllum }\end{array}$ \\
\hline Phaeophyta & Phaeophyceae & Fucales & Sargassaceae & Sargassum & Sargassum polycystum \\
\hline Phaeophyta & Phaeophyceae & Dictyotales & Dictyotaceae & Dictyota & Dictyota pinnatifida \\
\hline Phaeophyta & Phaeophyceae & Dictyotales & Dictyotaceae & Padina & Padina australis \\
\hline
\end{tabular}

Tabel 3. Klasifikasi Alga Merah (Rhodophyta)

\begin{tabular}{|c|c|c|c|c|c|}
\hline Divisi & Kelas & Ordo & Famili & Genus & Spesies \\
\hline Rhodophyta & Florideophyceae & Gracilariales & Gracilariaceae & Gracilaria & Gracilaria corticata \\
\hline Rhodophyta & Rhodophyceae & Gigartinales & Solieriaceae & Eucheuma & $\begin{array}{l}\text { Eucheuma } \\
\text { spinosum }\end{array}$ \\
\hline Rhodophyta & Florideophyceae & Gracilariales & Gracilariaceae & Gracilaria & $\begin{array}{l}\text { Gracilaria } \\
\text { salicornia C. } \\
\text { Agaradh }\end{array}$ \\
\hline Rhodophyta & Rhodophyceae & Ceramiales & Rhodomelaceae & Acanthophora & $\begin{array}{l}\text { Achanthopora } \\
\text { spicifera }\end{array}$ \\
\hline Rhodophyta & Florideophyceae & Ceramiales & Rhodomelaceae & Acanthophora & $\begin{array}{l}\text { Achanthopora } \\
\text { muscoides }\end{array}$ \\
\hline
\end{tabular}

Tabel 4. Klasifikasi Alga Hijau (Chlorophyta)

\begin{tabular}{cllcll}
\hline \multicolumn{1}{c}{ Divisi } & \multicolumn{1}{c}{ Kelas } & Ordo & Famili & \multicolumn{1}{c}{ Genus } & \multicolumn{1}{c}{ Spesies } \\
\hline Chlorophyta & Ulvophyceae & Ulvaves & Ulvaceae & Ulva & Ulva flexuosa \\
Chlorophyta & Chlorophyceae & Ulvales & Ulvaceae & Enteromorpha & Ulva reticulata \\
Chlorophyta & Ulvophyceae & Ulvales & Ulvaceae & Ulva L. & Ulva compress L. \\
\hline
\end{tabular}

\section{A. Alga Coklat}

\section{Hormophysa triquetra}

Thallus Hormophysa triquetra berwarna cokelat tua sampai coklat gelap, panjang berkisar 10-40 $\mathrm{cm}$, dengan batang pendek dan banyak cabang primernya, pertumbuhannya terbatas dengan lateralnya besar dan banyak. Sebaran Hormophysa triquetra tumbuh melekat pada substrat yang keras seperti rataan terumbu karang dengan dominasi populasinya bercampur dengan Sargassum oligocystum, Padina dan
Dictyosphaeria vers luysii dengan holdfastnya yang berbentuk cakram kecil (Gambar 1) (Heijs, 1985).

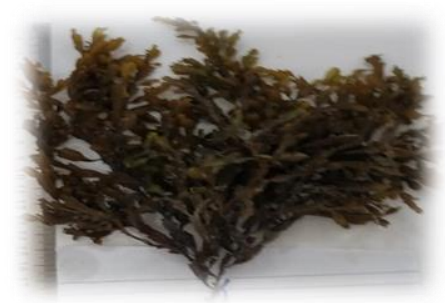

Gambar 1. Hormophysa triquetra 


\section{Sargassum muticum}

Sargassum muticum memiliki panjang daun lebih dari 1 meter, batangnya lurus dengan cabang oval pipih dan mempunyai kantung gas berbentuk bulat (Clemence, 2008). bagian ujung batang terdapat daun yang memanjang. Cabang pertama memiliki sedikit pelapis (daun) panjang seikitar $1,5 \mathrm{~cm}$ dengan tepinya bergigi. Panjang tanaman berkisar 1,5-2 m Habitatnya melekat pada substrat berbatu dan sedikit berpasir (Deysher \& Norton 1982).

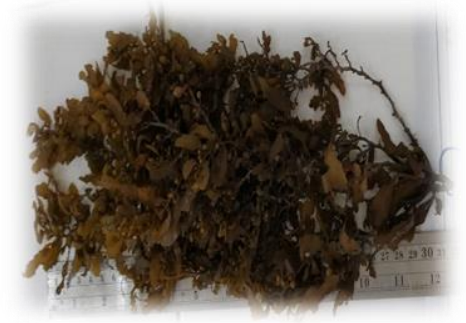

Gambar 2. Sargasssum muticum

\section{Turbinaria ornata (Turner) J. Agardh}

Thallus Turbinaria ornata (Turner) J. Agardh tegak dengan bentuk daun agak membulat, umumnya membentuk corong dengan dikelilingi baris duri kaku disekitar tepian daun dan terletak tidak beraturan, bagian tengah daun melengkung ke dalam berwarna cokelat gelap dan membentuk rhizoid alat pelekat; hidup pada substrat berkarang pada habitat intertidal berbatu yang terbuka, daerah pasang surut (Zubia et al, 2004).

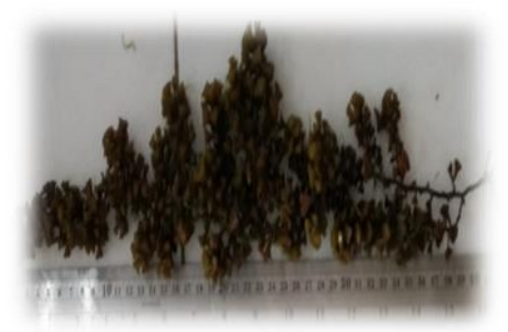

Gambar 3. Turbinaria ornata (Turner) J.

\section{Dictyota pinnatifida}

$$
\text { Argadh }
$$

Tanaman ini pada bagian yang lebih tua berwarna coklat tua dan berwarna coklat muda pada bagian yang masih muda, panjangnya berkisar dari 10-30 cm (Tronholm 2010). Berdaun kecil dan bercabang banyak, cabangcabang lebat ke arah hulu daun dan semakin sedikit cabang pada bagian ujung, tumbuh pada kondisi lingkungan yang keruh (Cunha et al, 2013).

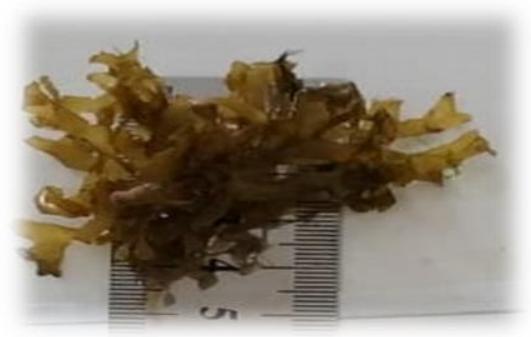

Gambar 4. Dictyota pinnatifida

\section{Sargassum polycystum C.A Agardh}

Panjang thallus Sargassum polycystum C.A Agardh berkisar 3,5-10 cm, daunnya kecil dan lonjong, lebar blade 0,5-1,5 cm, pada pinggir daun terdapat daun yang bergerigi atau seperti gergaji dan ujungnya runcing. Habitat dan sebaran tumbuh pada substrat berbatu seperti di daerah rataan terumbu karang dan berada pada zona pasang surut wilayah pesisir (Nasab et al, 2020).

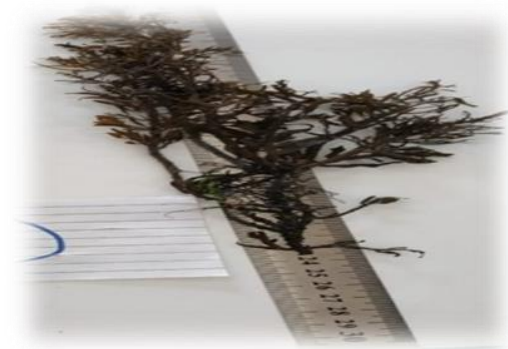

Gambar 5. Sargassum polycystum C. Agardh

\section{Sargasum plagyophyllum}

Alga berwarna kecoklatan, thallus bercabang berbentuk lembaran seperti daun bergelombang, pinggir bergerigi, ujung runcing dengan permukaan licin dan agak kaku, dari nudus terdapat bulatan-bulatan banyak menyerupai buah. Panjangnya antara $9-10 \mathrm{~cm}$. Tumbuh menempel pada substrat dasar perairan yang dipengaruhi oleh arus dan ombak, serta pertumbuhan alga ini tumbuh pada daerah tubir dan membentuk rumpun besar dengan cabang thalli terdapat gelembng udara (vesicle) yang muncul di permukaan air (Triastinurmiatiningsih et al, 2011).

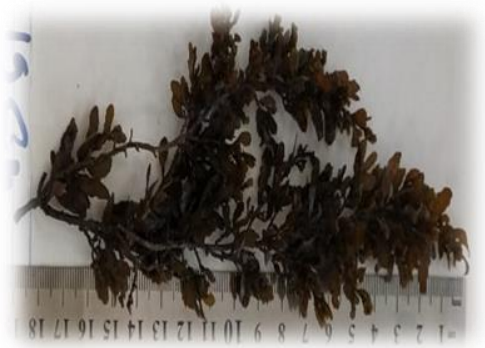

Gambar 6. Sargasum plagyophyllum 


\section{Padina australis}

Padina australis memiliki bentuk thallus seperti kipas, membentuk lembaran tipis (lobus) dengan garis-garis berambut radial dan perkapuran dipermukaan daun. daunnya halus dan licin, panjangnya 6-7 $\mathrm{cm}$. Holdfast berbentuk cakram kecil serta menempel pada rataan terumbu, lebih banyak terdapat pada zona intertidal dan tumbuh pada substrat berbatu serta membentuk zonasi (Abdullah et al, 2020).

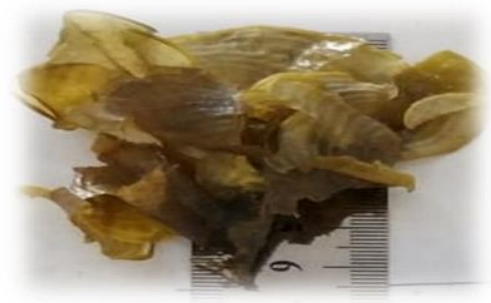

Gambar 7. Padina australis

\section{B. Alga Merah}

\section{Gracilaria corticata}

Bentuk thallusnya tegak, panjangnya mencapai $15 \mathrm{~cm}$, lebar hingga $5 \mathrm{~cm}$, bercabang banyak pada bagian atas (ujung) tanaman sehingga menjadi lebat sedangkan pada pangkal tidak terlalu lebat (Iyer et al, 2004). Warna thallus kemerahan agak merah-kekuningan, sering ditemukan bintik-bintik dengan beranekaragam pada thallus serta pada bagian ujung (apeks) berbentuk runcing melekat pada batu karang dengan cakram yang terdapat pada dasar thallus ( $\underline{\text { Rao }}, 1972)$.

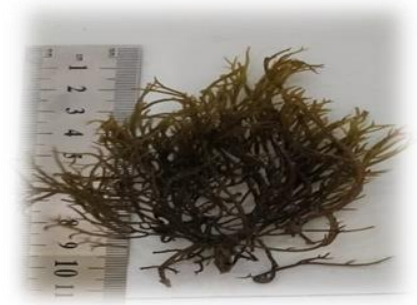

Gambar 8. Gracilaria corticata

\section{Eucheuma Spinosum}

E. spinosum memiliki ciri khusus thallus berbentuk silindris dengan permukaan licin, lunak, warna hijau kuning, terdapat duri yang tumbuh berderet melingkari thallus dengan interval yang bervariasi sehingga membentuk ruas-ruas thallus diantara lingkaran duri. Percabangan berlawanan atau berselang-seling dan teratur pada deretan duri antar ruas Ujung percabangan meruncing dan setiap percabangan mudah melekat pada substrat (Aslan, 1991; Meriam et al, 2016).

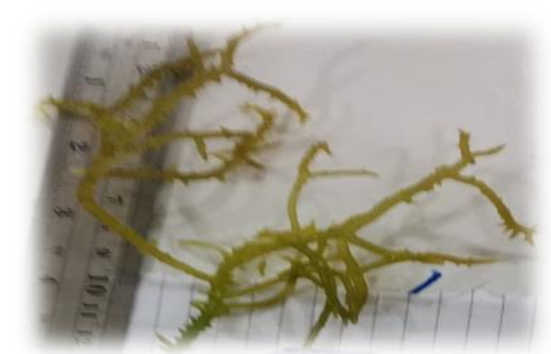

Gambar 9. Eucheuma Spinosum

\section{Glacilaria salicornia (C. Agardh)}

Gracilaria salicornia C. Agardh memiliki bentuk thallus bulat, licin, bercabang membentuk rumpun, dan beruas, warna merah keunguan, elastis seperti tulang rawan, tinggi mencapai $6 \mathrm{~cm}$, bagian holdfast berbentuk discoid (bundar dan pipih menyerupai cakram) thallusnya bersifat cartilaginous atau bersifat rapuh juga mudah terlepas dari ruasnya saat terhempas gelombang (Atmadja et al, 1996). Berwarna hijau kekuningan sampai orange di perairan jernih. Habitat alga ini yaitu substrat karang, batu dan berpasir.

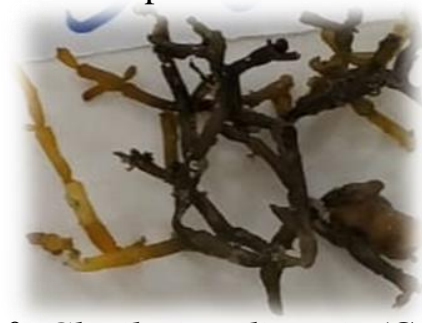

Gambar 10. Glacilaria salicornia (C. Agardh)

\section{Achanthopora spicifera}

Alga ini berwarna cokelat kekuningan sampai cokelat tua, cabangnya banyak dan kecil agak kaku dengan bintil-bintil yang mencuat kesamping dengan permukaan kasar, bercabang banyak pada rumpun dan padat. Alga ini panjangnya berkisar antara 9-10 cm, memiliki cabang utama yang pendek, bentuknya tidak beraturan. Tumbuh melekat pada batu karang dan pecahan karang. Habitatnya substrat berbatu, karang atau substrat keras lainnya yang gerakan air arus atau gelombangnya kecil (Katamang et al, 2016).

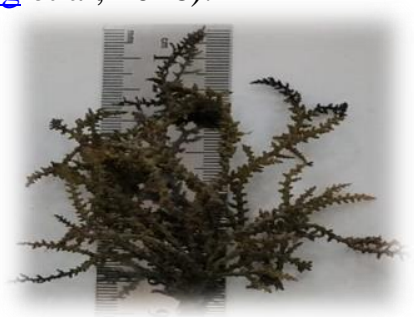

Gambar 11. Achanthopora spicifera 


\section{Achanthopora muscoides}

Karakteristik thalusnya tegak, berwarna coklat tua dan cartikaginous bercabang lebat tidak teratur serta membentuk rumpun. Cabang utama berbentuk silindris, serta permukaan thallus terdapat bintil-bintil seperti duri tumpul yang rapat, berdiameter $0,7-1,9 \mathrm{~mm}$, meruncing ke ujung. Korteks terdiri dari sekitar dua lapisan sel bulat sangat kecil; cystocarp berbentuk bulat telur, berbentuk guci dengan bukaan besar (Sofyana, 2016).

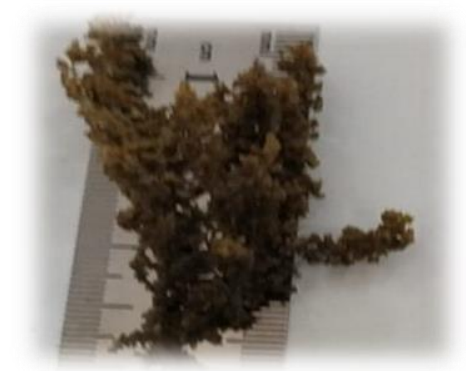

Gambar 12. Achanthopora muscoides

\section{Alga Hijau}

Ulva flexuosa syn. Enteromorpha flexuosa

Ulva flexuosa memiliki thallus tubular yang halus, linear dan seragam, dapat memiliki satu hingga beberapa thallus, warna berkisar dari tembus gelap kehijau muda, dan memiliki wilayah rizoidal yang sangat kecil (Hayden 2003). Flexuosa cenderung tidak bercabang, memiliki filamen bercabang dan biasanya lebih ramping. Ulva flexuosa memiliki batang yang sangat bercabang dengan sel-sel yang panjang yang tersusun dalam barisan panjang. Barisbaris ini agak tidak teratur di bagian tengah thalli yang lebih menjadi satu baris (Mares et al. 2011). Panjangnya mencapai $30 \mathrm{~cm}$. Ulva flexuosa melekat pada substrat oleh cakram basal kecil dan bulat (Sahoo et al, 2003).

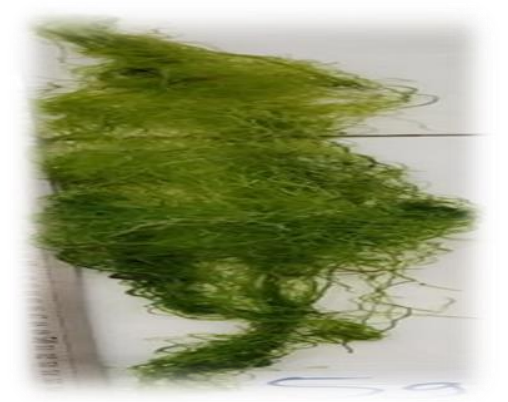

Gambar 13. Ulva flexuosa syn. Enteromorphaflexuosa

\section{Ulva reticulata}

Thallus Ulva reticulata ini berupa lembaran kecil dengan ukuran lebar $2 \mathrm{~mm}$ membentuk rumpun menyerupai jaring dengan berekspansi radial berwarna hijau muda atau hijau tua. Habitat dan sebarannya di zona intertidal pada perairan pasang surut, pada substrat yang keras seperti berpasir, berbatu, ulva reticulata memiliki foliose thallus yang dan menjadi berlubang karena usia (Largo et al, 2004).

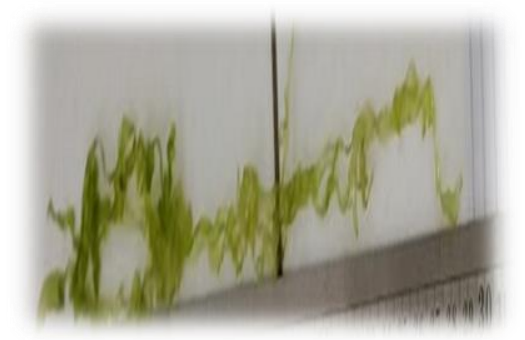

Gambar 14. Ulva reticulate

\section{Ulva compressa $L$.}

Panjang thallus 20-40 cm, bercabang banyak di pangkalan, cabang melebar keatas (ujung), lebar daun 0,5-3 cm, dengan lapisan sel yang berdekatan tetapi tidak melekat. Spesies Ulva compressa $\mathrm{L}$. dapat tumbuh hingga $45 \mathrm{~cm}$ dan hidupnya pada zona intertidal antara lingkungan payau dan laut (Edwards et al, 2012; Loughnane et al, 2008).

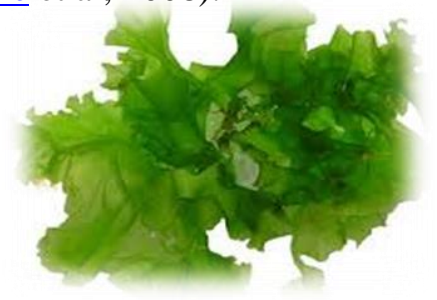

Gambar 15. Ulva compressa L.

\section{SIMPULAN}

Berdasarkan hasil penelitian maka dapat disimpulkan bahwa makroalga yang ditemui di perairan Moudolung Kabupaten Sumba Timur terdiri dari 3 kelas makroalga yaitu alga cokelat 7 spesies (Hormophysa triquetra, Sargasssum muticum, Turbinaria ornata (Turner) J. Agardh, Sargasum plagyophyllum, Sargassum polycystum, Dictyota pinnatifida dan Padina australis), alga merah 5 spesies (Gracilaria corticata, Eucheuma spinosum, Gracilaria salicornia C. Agaradh, Achanthopora spicifera dan Achanthopora muscoides), dan alga hijau 3 
spesies (Ulva flexuosa, Ulva reticulate dan Ulva compressa L.).

\section{UCAPAN TERIMA KASIH}

Ucapan terima kasih kami sampaikan kepada Universitas Kristen Wira Wacana Sumba yang telah membiayai penelitian kami melalui Skim Penelitian Dosen Mandiri Tahun 2019.

\section{REFERENSI}

Abdullah, A.M., Akhtar, A., Rahman, M.F., Kamal, A.H.M., Karim, N.U \& Hassan M.L. 2020. Habitat structure and diversity patterns of seaweeds in the coastal waters of Saint Martin's Island, Bay of Bengal, Bangladesh. Regional Studies in Marine Science. 33.100959.

Aslan, L.M. 1991. Budidaya Rumput Laut. Penerbit Kanisius, Yogyakarta.

Atmadja,W.S., Kadi, A., Sulistijo \& Rachmaniar. 1996. Pengenalan jenis-jenis rumput laut di Indonesia. Pusat Penelitian dan Pengembangan Oseanologi-LIPI, Jakarta: 191 hal.

Clemence, B. 2008. Sargassum Muticum, Wireweed. Fall. http://depts.washington.edu/oldenlab/wor dpress/wpcontent/uploads/2013/03/Sarga ssum-Muticum_Clemence.pdf. Diakses tanggal 20 April 2020.

Cordero, P.A.J. 1980. Taxonomy and Distribution of Philiphine useful Seaweed. National Research Council of the Philiphines. Bictum Taging Metro Manila Philiphines.

Cunha T.J., Guth, A.Z., Bromberg, S. \& Sumida P.Y.G. 2013. Macrofauna Assosiated with The Brown Algae Dictyota spp. (Phaeophyceae, Dictyotaceae) in The Sebastiao Gomes Reef and Abrolhos Archipelago, Bahia, Brazil. Continental Shelf Research. 70: 140149. http://dx.doi.org/10.1016/j.csr.2013. 09.001

Dawson, E.Y. 1966. Marine Botan. New York, Chicago, San Fransisco, Toronto, London Inc.

Deysher, L.E. \& Norton, T.A. 1982. The Reproductive Ecology of Sargassum muticum at different Latitudes. Ecology Project, 531 USA.

Dhargalkar, V.K \& Kavlekar, D. 2004. Seaweed: A Field Manual. National
Institute of Oceanography, Dona Paula, Goa. $403 \quad 004$. http://drs.nio.org/drs/bitstream/handle/22 64/96/SeaweedsManual.pdf;jsessionid $=6$ FBF964509DC0D0B727A4FF8380ABF 75 ? sequence $=1$

Dwimayasanti, R \& Kurnianto. 2018. Komunitas Makroalga di Perairan Tayando-Tam, Maluku Tenggara. Oseanologi dan Limnologi di Indonesia 3(1):39- 48

Edwars, M., Hanniffy, D., Heesch, S., Hernandez, K.J., Moniz, M., Quequineur, B., Ratcliff, J., Soler, F.A \& Wan, A. 2012. Makroalgae Fact-sheets. Ryan Institute Environmental, Marine and Energy Research. 40p.

Fitria, L., Dewiyanti, I \& Fadli, N. 2019. Struktur Komunitas dan Persentase Luas Penutupan Makroalga di Perairan Teluk Kabupaten Aceh Selatan. Jurnal La'ot. 2(2): 94-105.

Handayani, T. 2017. Asesmen Rumput Laut Potensial Penghasil Fikokoloid Untuk Dikembangkan sebagai Bahan Baku Industri. Laporan Akhir Tahun LIPI, 26 Hal.

Hayden, H., Blomster, J., Maggs C.A., Silva P., Stanhope M.J \& Waaland, J.R. 2003. Linnaeus was right all along: Ulva and Enteromorpha are not distinct genera. European Journal of Phycology. 38: 277294

Heijs, F. M. L. 1985. Makroalgal Component in Monospecific Seagrass Beds From Papua New Guinea. Aquatic Botany. 291-324.

Iyer, R., Clerck, O.D., Bolton, J.J \& Coyne, V.E. 2004. Morphological and taxonomic studies of Gracilaria and Gracilariopsis spesies (Gracilariales, Rhodophyta) from South Africa. South African Journal of Botany. 70(4): 521-539.

Katamang, A.V., Rumampuk, N.D.C \& Gerung, G.S. 2016. Telaah Bentuk Sel Acanthophora specifera dari Pantai Beton Panjang Mokupa Sulawesi Utara. Jurnal Pesisir dan Laut Tropis. 4(1):26-29.

Kurniawan, R. 2018. Keanekaragaman Jenis Makroalga di Perairan Laut Desa Teluk Bakau Kabupaten Bintan Kepulauan Riau. Skripsi, Fakultas Ilmu Kelautan dan Perikanan Universitas Maritim Raja Ali Haji, Tanjungpinang. 
Lapu, P. 2013. Esplorasi Makroalagae di Perairan Rutong dan Leihari, Kecamatan Leitimur Kota Ambon. Prosiding FMIPA Universitas Pattimura 2013 - ISBN: 978602-97522-0-5. Hal 36-40

Largo, D.B., Sembrano, J., Hiraoka, M \& Ohno, M. 2004. Taxonomic and ecological profile of 'green tide' species of Ulva (Ulvales, Chlorophyta) in central Philippines. Hydrobiologia. 512: $247-$ 253.

Loughnane, C.J., McIvor, L.M., Rindi, F., Stengel, D.B \& Guiry, M.D. 2008. Morphology, rbcL phylogeny and distribution of distromatic Ulva (Ulvophyceae, Chlorophyta) in Ireland and southern Britain. Phycologiaa. 47(4): 416-429.

Mares, J., Leskinen, E., Sitkowska, M., Celova, O.S \& Blomster, J. 2011. True Identity of the European Freshwater Ulva (Chlorophyta, Ulvophyceae) Revealed By A Combined Molecular and Morphological Approach). Phycological Society of America. 47: 1177-1192.

Marianingsih, P., Amelia, E \& Suroto, T. Inventarisasi dan Identifikasi makroalga di Perairan Pulau Untung Jawa. Prosiding Semirata FMIPA Universitas Lampung. Hal. 219-225.

Meriam, W.P.M., Kepel, R.C \& Lumingas, L.J.L. 2016. Inventarisasi Makroalga Di Perairan Pesisir Pulau Mantehage Kecamatan Wori, Kabupaten Minahasa Utara, Provinsi Sulawesi Utara. Jurnal Ilmiah Platax. 4(2): 2302-3589.

Messyasz, B., Pikosz, M., Schroeder, G., Łęska, B \& Fabrowska, J. 2015. Identification and Ecology of Macroalgae Species Existing in Poland. Marine Algae Extracts. 15 40. doi:10.1002/9783527679577.ch2.

Nasab, S.B., Homaei, A \& Karami, L. 2020. Kinetic Of $\alpha$-amilase Inhibition by Gracilaria corticata and Sargassum angustifolium extracts and zinc oxide Nanoparticles. Biocatalysis and Agricultural Biotechnology. 23: 101478 https://doi.org/10.1016/j.bcab.2019.1014 78.

Nurafni, N., Alwi, D \& Baco, S. 2020. Analisis Indeks Ekologi Makroalga di Perairan Desa Juanga Kabupaten Pulau
Morotai. Jurnal Ilmiah Wahana Pendidikan. 6(1): 96-103. https://doi.org/10.5281/zenodo.3690268.

Pakidi, C.S \& Suwoyo, H.S. 2017. Potensi dan Pemanfaatan Bahan Aktif Alga Cokelat Sargassum sp. Octopus. 6(1): 551-562.

Radiarta, I.N \& Erlania. 2015. Indeks Kualitas Air Dan Sebaran Nutrien Sekitar Budidaya Laut Terintegritas Di Perairan Teluk Ekas, Nusa Tenggara Barat: Aspek Penting Budidaya Rumput Laut. Jurnal Riset Akuakultur. 10(1): 141-152.

Rao, M.U. 1972. On The Gracilaruceae of The Seas Around India. J; mar. Biol. Ass India. 14(2): 671-69.

[SNI] Standar Nasional Indonesia SNI 7904:2013. Produksi Bibit Rumput Laut grasilaria (Grasilariaverrucosa) dengan Metode Sebar di tambak.

Sahoo, N., Mahapatra, D.R., Jagadeesh, G., Gopalakrishnan, S \& Reddy, K.P.J. 2003. An accelerometer balance system for measurement of aerodynamic force coefficients over blunt bodies in a hypersonic shock tunnel. Measurement Science and Technology, 14(3): 260272. doi:10.1088/0957-0233/14/3/303.

Santosa, J., Yoshie, S.Y \& Suzuki, T. 2004. Antioxidant Activity of Methanol Extracts from Indonesian Seaweeds in an Oil Emulsion Model. Fisheries Science. 70:183-188.

Setyawan, I.B., Prihanta, W \& Purwanti, E. 2015. Identifikasi Keanekaragaman dan Pola Penyebaran Makroalga di Daerah Pasang Surut Pantai Pidakan Kabupaten Pacitan sebagai Sumber Belajar Biologi. Jurnal Pendidikan Biologi Indonesia. 1(1): 78-88.

Sofyan, A. 2016. Distribusi, Kelimpahan dan Pemanfaatan Makroalga Lokal di Sepanjang Pantai Selatan Gunungkidul, Yogyakarta. Skripsi, Fakultas Sains dan Teknologi Universitas Islam Negeri Sunan Kalijaga, Yogyakarta.

Taylor, W.R. 1960. Marine Algae of Tropical and Subtropical Coast of the Americas. TheUniversity of Michigan Press, USA.

Triastinurmiatiningsih., Ismanto \& Ertina. 2011. Variasi Morfologi dan Anatomi Sargassum spp. Di Pantai Bayah Banten. Ekologia. 11(2): 1-10. 
Tronholm, A. 2010. Species Delimitation, Taxonomy, and Biogeography of Dictyota in Europe (Dictyotales, Phaeophyceae). Phycological Society of America. 46: 1301-1321.

Zubia, M \& Payri, C. 2004. Mapping and Biomass Estimation of The Invasive Brown Algae Turbinaria ornata (Turner) J. Agardh and Sargassum mangarevense (Grunow) Setchell On Heterogeneous Tahitian Coral Reefs Using 4-meter Resolution IKONOS Satelite Data. Coral Reefs. 23:26-38 